\title{
SECONDARY MINERALS IN VOLCANIC CAVES: DATA FROM HAWAI'I
}

\author{
William B. White \\ Materials Research Institute and Department of Geosciences, The Pennsylvania State University, University Park, PA 16802, wbw2@psu.edu
}

\begin{abstract}
Lava tube caves contain a variety of secondary minerals formed by seepage waters extracting components from the overlying soils and basalt and depositing them as crusts, crystals, and small speleothems in the underlying tubes. Fifty one specimens were analyzed in the course of a reconnaissance of a selection of caves on Hawai' 1 . Many of these were from caves at low elevation where the cave environment is wet and at ambient temperature. Some were from a cave at 2900 meters on Mauna Loa where conditions were much drier. Minerals in hot fumarole caves in the Kilauea Caldera were observed but not sampled. Mineral identifications were made by X-ray diffraction with some assistance from a scanning electron microscope with energy dispersive X-ray detector for rough chemical analysis. Calcite is surprisingly common, appearing in the form of small coralloids and other crusts and coatings. Gypsum is common as crusts and as puffballs. Two other sulfate salts, thenardite and mirabilite, were identified. Two unusual mineral deposits contained the transition metal ions vanadium and copper. Bright olive-green patches in Lama Lua Cave were characterized as a hydrated copper-vanadium silicate with composition $\mathrm{Mg}_{2} \mathrm{Cu}_{4}\left(\mathrm{VO}_{4}\right)_{2} \mathrm{Si}_{5} \mathrm{O}_{13}\left(\mathrm{H}_{2} \mathrm{O}\right)_{5.6}$. Although the mineral produced a high quality X-ray diffraction pattern, the pattern did not match any minerals in the database. The blue-green stalactites in the Kapuka Kanohina system are a non-crystalline hydrated copper silicate coating lava stalactites.
\end{abstract}

\section{INTRODUCTION}

The term volcanic cave includes lava tubes, tumulous caves, fracture caves, volcanic vents and other cavernous openings produced by volcanic processes. Decoration of these caves can be broadly separated into two categories. Primary decorations are those features formed at the same time or in the closing stages of the process that formed the caves themselves (there seems to be some argument as to whether or not such features should be called speleothems). These include lava stalactites, lava stalagmites and other features formed by dripping and freezing of lava (Baird et al., 1985). Secondary decorations are mineral deposits that formed after the primary cave opening had cooled or at least partially cooled. Some of these result from steam and volcanic gases in fumarole caves and other openings that are still well above regional ambient temperatures, although below that of the original lava. Others result from the leaching of material by infiltrating groundwater and the subsequent deposition of minerals in underlying lava tubes. Although investigations of secondary minerals in volcanic caves are less numerous than investigations of minerals in limestone caves, the number of observed minerals is surprisingly large (Hill and Forti, 1997; Forti, 2000; 2005;). The reason for the mineralogical diversity is the variety of environments in volcanic settings, each with a unique set of conditions for mineral deposition (Forti, 2005).

Cavers exploring the lava tube systems on Hawai'i (the Big Island) have long noticed a variety of speleothems, some of which look much like the speleothems from limestone caves. They have also reported several brightlycolored unknown minerals. The present paper presents the results of a reconnaissance investigation during which samples were analyzed from nine caves, mostly at low elevation.

\section{Field Investigations, Sampling, And Analytical Methods}

The results reported in this paper are based on 51 samples collected during January 2005. Particularly interesting mineralized areas were pointed out by the cavers doing the exploration and mapping. Small samples, masses generally in the range of a few grams, were collected in sealed sample bottles. Great care was taken to do minimal damage to the caves. Previously broken fragments from the floor were used whenever possible. No further precautions were taken to preserve the samples, although samples that had been wet in the cave remained wet when the samples were removed from the bottles in the laboratory.

All samples were examined under a binocular microscope. Selected portions of each sample were ground to powder that was then used to obtain X-ray powder diffraction patterns. The instrument was a Scintag diffractometer with a $\mathrm{CuK} \alpha \mathrm{X}$-ray source. Powder patterns were matched by a computer search routine with the reference patterns in the database of the International Committee for Powder Diffraction Standards. Paper copy of the X-ray patterns could be inspected visually for anomalous features. 


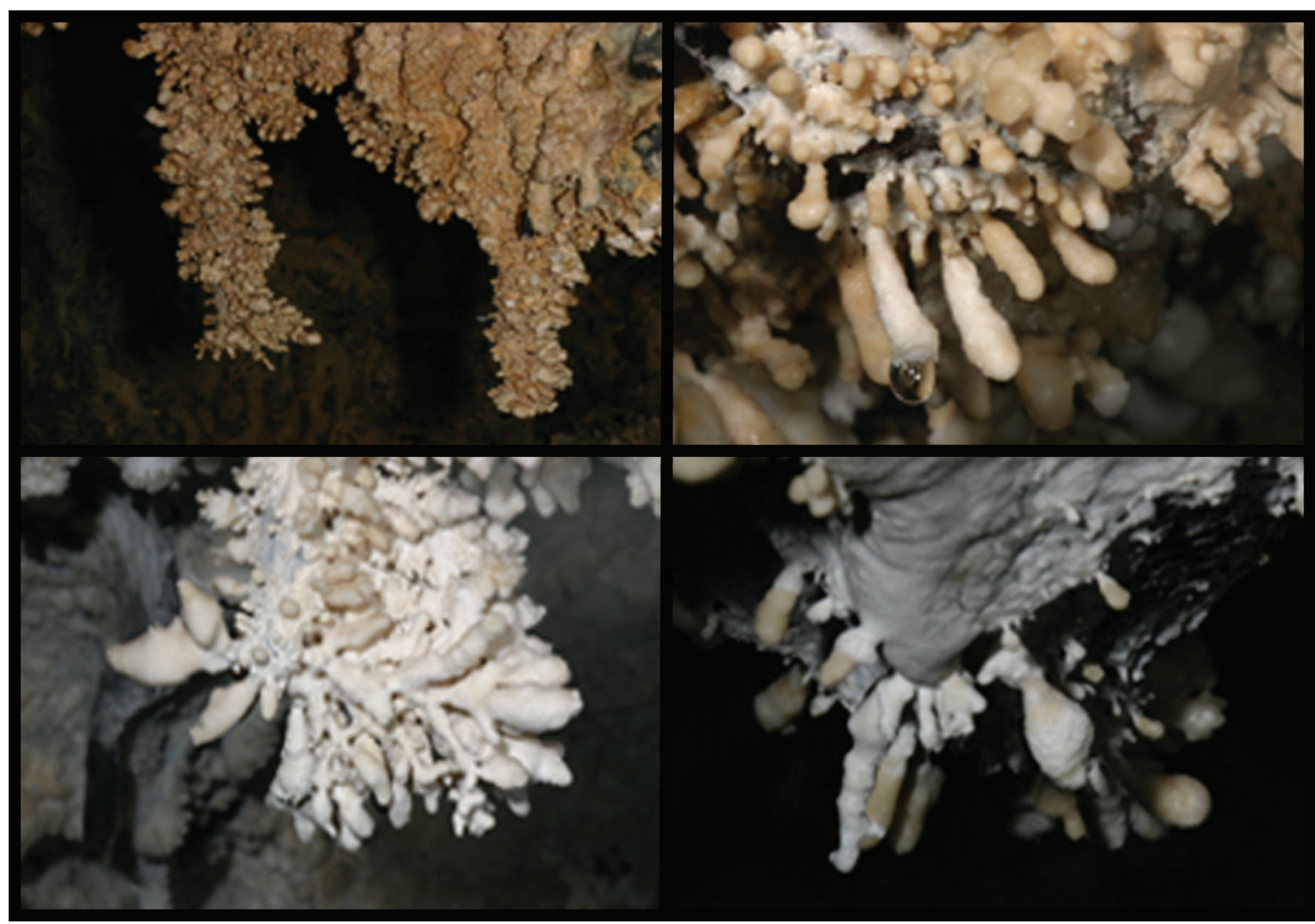

Figure 1. A representative selection of coralloid speleothems from Puff Ball Hall, Hualalai Ranch System. Individual coralloids are in the range of $1-3 \mathrm{~cm}$ in length.

For most of the samples, the X-ray diffraction patterns provided an unambiguous identification. However, two brightly colored samples required more extensive characterization tools. In addition to X-ray, these samples were also examined in a scanning electron microscope with an attachment to determine rough elemental composition by energy dispersive X-ray spectroscopy. For the Lama Lua olive-green coating, a more accurate chemical analysis was obtained with a Cameca Electron Microprobe. Infrared spectra were also obtained using a Nicholet Fourier transform spectrometer to provide additional structural information.

\section{Mineral Descriptions AND IDENTIFICATION}

Although similar features appear in many of the caves, it is convenient to organize the results according to the cave from which the key specimens were obtained.

\section{The Hualalai Ranch System and Other Kona Area Caves}

The Hualalai Ranch System has been mainly explored by cavers from the Butler Cave Conservation Society. Detailed exploration and survey has spliced together many previously unconnected fragments to produce $27.63 \mathrm{~km}$ of survey as of 2007. The sampling was concentrated in Puff
Ball Hall, a highly mineralized area. In this part of the cave are various white coatings, white masses of material on the floor, white puff balls, and many coralloid type deposits. Twelve samples were collected in this section of the Hualalai Ranch System with a view of obtaining a representative cross section of the mineralogy.

Figure 1 displays a selection of typical coralloids. X-ray diffraction shows that the coralloids are composed of wellcrystallized calcite. They are layered, generally colored tan to brown, and have no obvious differences from coralloids found in limestone caves. X-ray diffraction measurements revealed that many of the crusts and the loose powder on the floors are also calcite. The positions of the diffraction lines were close to those for pure $\mathrm{CaCO}_{3}$ in all samples, showing that the magnesium content of the calcite is low. Palmer and Palmer (2006) estimated 2.2 mole percent magnesium in a sample from Refuge Cave (Kapuka-Kanohina System). Some samples of the loose, granular material from the floor produced calcite X-ray patterns on which were superimposed broader and weaker peaks that indicated a second phase of montmorillonite or a related smectite mineral (Fig. 2). Consistent with this interpretation is the somewhat sticky texture noted when the samples were ground in preparation for X-ray diffraction measurements.

The puff balls of Puff Ball Hall consist of buttonshaped speleothems ranging from one to two $\mathrm{cm}$ in 


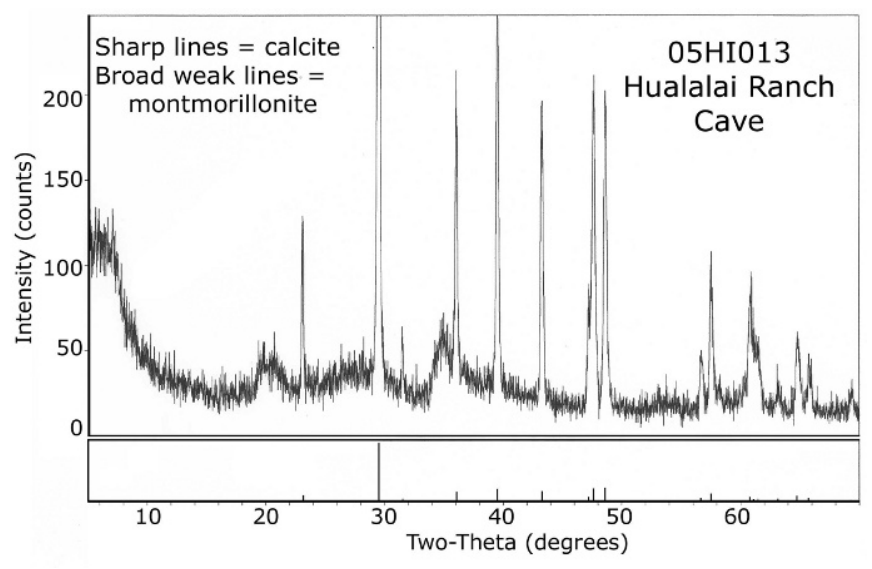

Figure 2. X-ray powder diffraction pattern of sample 05HI013, loose white powder from ledges on the walls of Puff Ball Hall, Hualalai Ranch System. The sharp diffraction peaks are due to calcite; the weaker, broader, and more noisy peaks are due to montmorillonite.

diameter (Fig. 3). X-ray diffraction shows that the puff balls have outer crusts of gypsum but the inside of the speleothems consists largely of calcite. Pure gypsum was found only in loose fragments and in some of the crusts and loose powders on the floors and ledges. As a guideline, hard nodular speleothems are calcite; soft fluffy speleothems are gypsum. No evidence was found for any other minerals, in spite of the fairly intensive sampling in this limited area.

A few samples were analyzed from other caves in the North Kona District. The results are:

Bee Cave (Davis, 2006), loose powder from floor: gypsum

Black Pellet Cave (Medville, 2005), white granular powder from floor: gypsum

Kiholo Bay Cave (Medville, 2006a), 0.5-1 cm lumps of chalky white powder in some parts and orange finegrained crystals in other parts. X-ray shows a mixture of $80 \%$ gypsum and $20 \%$ calcite.

\section{Lama Lua Cave}

Lama Lua Cave is a 5523-m-tube in a 2100 year pahoehoe flow about $22 \mathrm{~km}$ north of Kailua-Kona. The main tube extends $3350 \mathrm{~m}$ down slope from the Lama Lua entrance (Medville, 2006b; Medville and Davis, 2007). Sampling was done through the Lama Lua entrance, an $8 \mathrm{~m}$ overhanging puka.

The first chamber below the puka is well decorated with coralloids very similar in appearance to those found in the Hualalai Ranch System. The area is wet and dripping. X-ray diffraction shows that three samples collected here consist entirely of well-crystallized calcite. One sample had a white mushy material coating over the coralloid, but the mushy material was also calcite. These samples exhibited a white luminescence under long wave $(365 \mathrm{~nm})$ ultraviolet light.

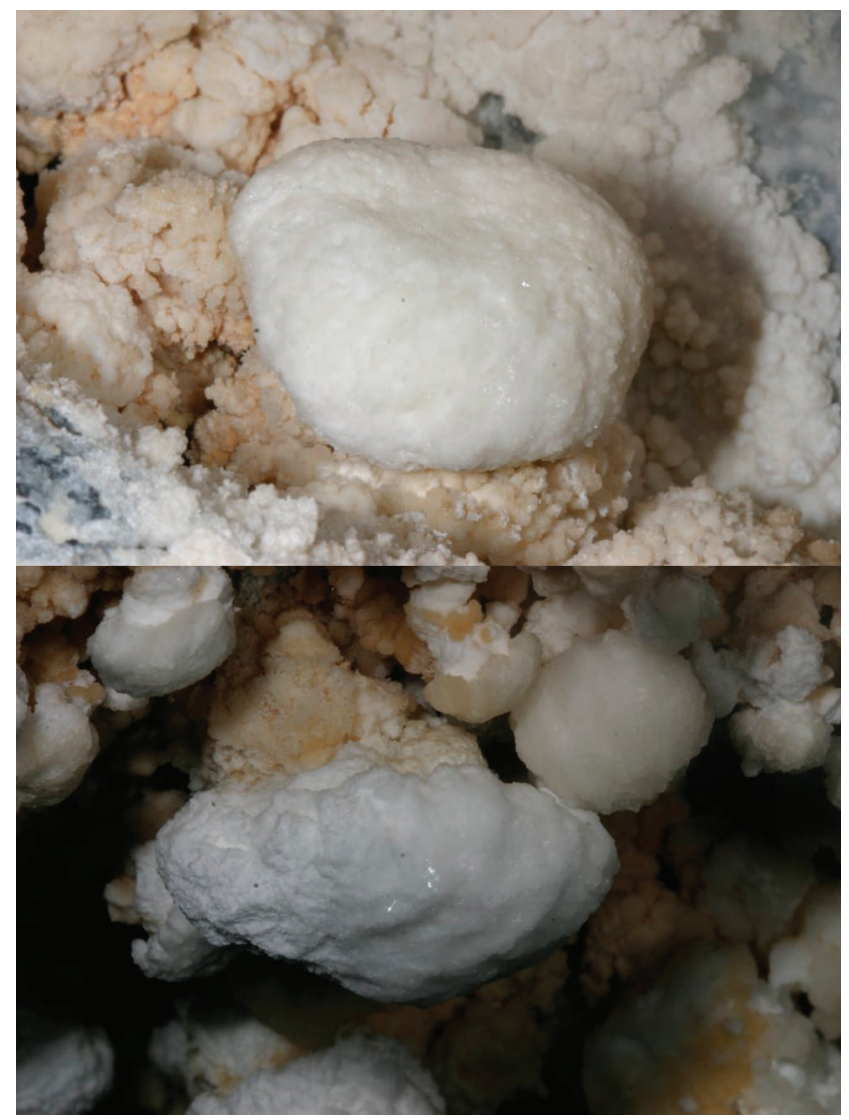

Figure 3. Two examples of puff balls from Puff Ball Hall, Hualalai Ranch System. Puffballs are about one cm in diameter.

The layered structure of these speleothems is not intrinsically different from the cave coral found in limestone caves.

About $500 \mathrm{~m}$ down tube from the entrance are several patches of olive-green mineral that appears to be sprayed onto the lava (Fig. 4). The deposits are thin layers completely coating upward-facing breakdown and some are related to fractures. The uniform coating implies that the coating is younger than the rockfall. Parts of these deposits are on broken slabs of breakdown so it was possible to collect several small chips from both mineralized areas. The mineral is in the form of a thin hard coating that was almost impossible to scrape from the underlying basalt. Examination by binocular microscope showed that the coating was spread uniformly over the vesicles in the underlying basalt. Under the microscope, the color and grain morphology appeared to be uniform suggesting that only one mineral was present. A scanning electron microscope image of the intact coating on a small chip of rock showed only featureless grains.

The X-ray emission spectrum, measured with the energy-dispersive detector on the SEM gives a rough chemical analysis (Fig. 5). The dominant elements in the green coating are $\mathrm{Ca}, \mathrm{Si}, \mathrm{V}$, and $\mathrm{Cu}$ with some $\mathrm{Fe}$ and $\mathrm{Al}$. By use of a diamond grinding bit on a miniature drill, it 


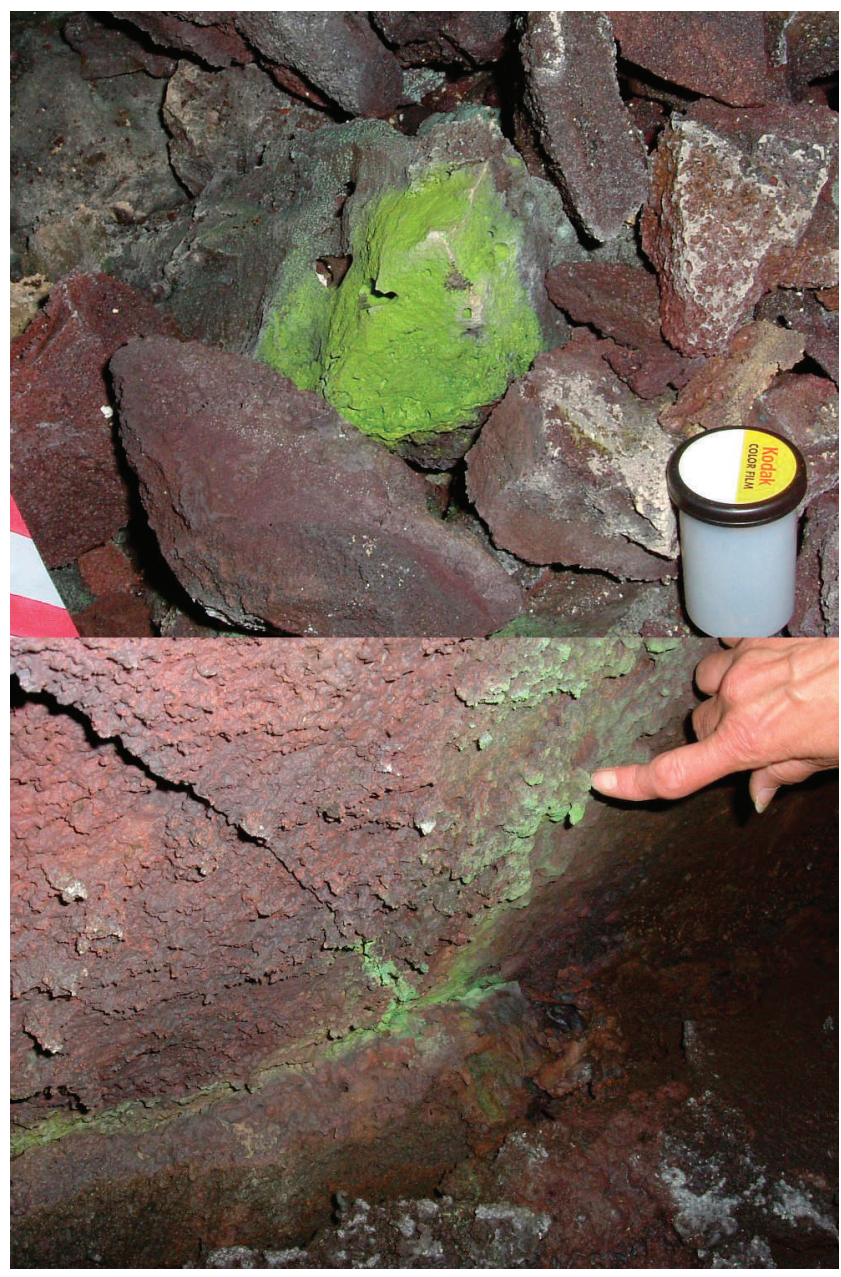

Figure 4. Green mineral patches in Lama Lua Cave.

was possible to obtain a few milligrams of relatively pure coating material, although the possibility of some contamination from the underlying rock cannot be eliminated. The scraping produced a sharp and very complex X-ray diffraction pattern (Table 1). The infrared spectrum of the scraping (Fig. 6) shows that the mineral is hydrated and that it is a silicate.

A quantitative chemical analysis was obtained on individual grains with the electron microprobe (Table 2). The general agreement between the seven analyses further supports the hypothesis that the coating consists of a single mineral. The analyst reported vanadium as $\mathrm{V}_{2} \mathrm{O}_{3}$, but both the color and the oxidizing environment of the cave make it more likely that vanadium is present in the pentavalent state. With a readjustment of $\mathrm{V}_{2} \mathrm{O}_{3}$ to $\mathrm{V}_{2} \mathrm{O}_{5}$, the mean composition of the green mineral can be calculated (Table 3). Weight concentrations were converted to mole fractions and these were normalized to produce a chemical formula. The total of the metal oxides is only $89.85 \%$. It can be assumed that the remaining $10.15 \%$ is water and/or $\mathrm{OH}^{-}$because the IR spectrum shows that the mineral is hydrated. The band at $1650 \mathrm{~cm}^{-1}$ in the infrared spectrum

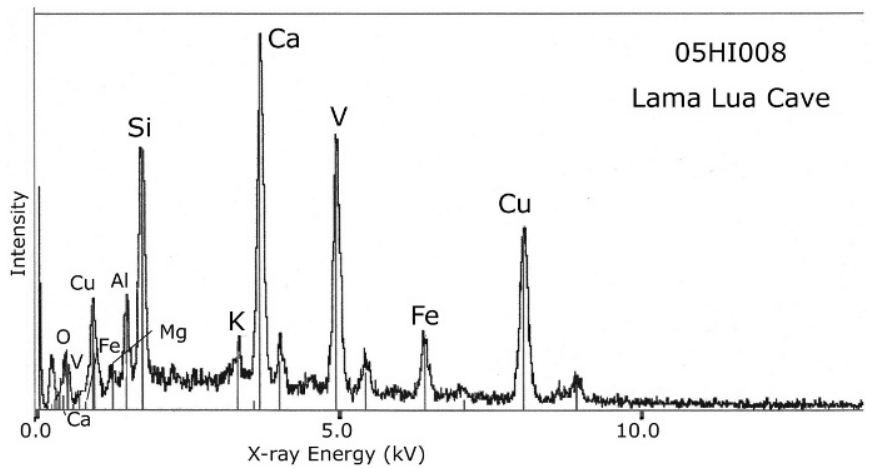

Figure 5. X-ray emission spectrum of the green mineral from Lama Lua Cave.

shows that at least some $\mathrm{H}_{2} \mathrm{O}$ is present, but the intense, broad $\mathrm{OH}$-stretching band does not distinguish between $\mathrm{OH}^{-}$and $\mathrm{H}_{2} \mathrm{O}$, so both could be present. The formula was calculated assuming $\mathrm{H}_{2} \mathrm{O}$ resulting in $\mathrm{Mg}_{2} \mathrm{Cu}_{4}\left(\mathrm{VO}_{4}\right)_{2}$ $\mathrm{Si}_{5} \mathrm{O}_{13}\left(\mathrm{H}_{2} \mathrm{O}\right)_{5.6}$ as the composition.

The rounding of the subscripts in Table 3 is within the accuracy of the chemical analyses, especially if it is assumed that $\mathrm{Al}$ substitutes for $\mathrm{Si}$. The placement of $\mathrm{Ca}$ in the formula is not known, although it could substitute for $\mathrm{Mg}$. Forti (2005) commented that minerals of the vanadate family had not been reported from volcanic caves, so the Lama Lua occurrence is of interest.

Specific mineral identification of the green Lama Lua phase has proved elusive. Evidence given above suggests a single phase with chemical composition close to the constructed formula. The most uncertainty is associated with the $\mathrm{H}_{2} \mathrm{O} / \mathrm{OH}$ content, but the metal ratios should be accurate. The X-ray diffraction pattern has many lines, some with low intensities (Table 1). To avoid the possibility that some of the weak lines are due to minor quantities of other phases, only those reflections with intensity greater than 20 were inserted in the search routine of the X-ray data base, with the constraint of the chemical composition. There were no matches. There is the possibility that the green deposit in Lama Lua Cave is a new mineral, but a much more comprehensive characterization of the material will be needed before it can be proposed as such.

\section{The Kipuka-Kanohina System}

The Kipuka-Kanohina System in an interconnected set of caves located in Kula Kai View Estates, about $70 \mathrm{~km}$ south of Kailua-Kona and $30 \mathrm{~km}$ north of South Point. At $26.5 \mathrm{~km}$, it is one of the longest lava tube complexes on the island (Elhard and Herrera, 2004; Coons, 2004). Two sections of the cave were investigated: the Kula Kai Caverns show cave and passages of the cave accessible from the Tapa Street entrance.

Kula Kai Caverns has an assortment of white coatings. Some of these are stringy deposits draped down the walls and have a distinctly organic appearance. Five samples 
Table 1. X-ray powder diffraction data for green Lama Lua specimen $05 \mathrm{HI} 008$.

\begin{tabular}{|c|c|c|}
\hline 2-Theta & $\mathrm{D}(\AA)$ & Intensity $\mathrm{I} / \mathrm{I}_{100}$ \\
\hline 8.8 & 10.037 & 15.6 \\
\hline 12.28 & 7.202 & 54.8 \\
\hline 15.16 & 5.84 & 6.4 \\
\hline 17.3 & 5.121 & 6 \\
\hline 19.94 & 4.449 & 8.6 \\
\hline 21.54 & 4.121 & 5.3 \\
\hline 21.96 & 4.044 & 53.9 \\
\hline 23.64 & 3.761 & 30.2 \\
\hline 24.12 & 3.687 & 12.9 \\
\hline 24.44 & 3.64 & 18 \\
\hline 25.62 & 3.474 & 33.3 \\
\hline 26.4 & 3.373 & 14.3 \\
\hline 26.72 & 3.334 & 6.7 \\
\hline 27.82 & 3.205 & 100 \\
\hline 28.42 & 3.138 & 14.4 \\
\hline 29.5 & 3.025 & 29.1 \\
\hline 29.78 & 2.997 & 62.8 \\
\hline 30.32 & 2.946 & 35.7 \\
\hline 30.8 & 2.901 & 17.6 \\
\hline 33.12 & 2.703 & 32.9 \\
\hline 33.74 & 2.654 & 15.8 \\
\hline 34.98 & 2.563 & 13.8 \\
\hline 35.62 & 2.518 & 38.1 \\
\hline 36.54 & 2.457 & 7.1 \\
\hline 36.77 & 2.442 & 5.4 \\
\hline 37.17 & 2.417 & 5.1 \\
\hline 37.7 & 2.384 & 8.5 \\
\hline 39.04 & 2.306 & 5.9 \\
\hline 39.27 & 2.292 & 6 \\
\hline 39.46 & 2.282 & 5.7 \\
\hline 40.82 & 2.209 & 7.4 \\
\hline 41.95 & 2.152 & 5 \\
\hline 42.36 & 2.132 & 15 \\
\hline 44.48 & 2.035 & 74.6 \\
\hline 49.33 & 1.846 & 6.6 \\
\hline 49.62 & 1.836 & 8.7 \\
\hline 50.76 & 1.797 & 5.7 \\
\hline 51.44 & 1.775 & 4.5 \\
\hline 52.02 & 1.757 & 4.3 \\
\hline 52.34 & 1.747 & 30 \\
\hline 54.09 & 1.694 & 5.2 \\
\hline 58.26 & 1.582 & 4.4 \\
\hline 61.07 & 1.516 & 4.2 \\
\hline 61.23 & 1.513 & 4.8 \\
\hline 62.38 & 1.487 & 6.5 \\
\hline 62.62 & 1.482 & 6.8 \\
\hline 64.02 & 1.453 & 4.5 \\
\hline 64.71 & 1.459 & 4.1 \\
\hline 66.31 & 1.408 & 3.8 \\
\hline 68.99 & 1.36 & 4.7 \\
\hline 84.75 & 1.143 & 11.5 \\
\hline
\end{tabular}

Table 1. Continued.

\begin{tabular}{llc}
\hline 2-Theta & $\mathrm{D}(\AA)$ & Intensity $\mathrm{I} / \mathrm{I}_{100}$ \\
\hline 85.03 & 1.14 & 10.5 \\
85.73 & 1.132 & 4.2 \\
87.56 & 1.113 & 3.6 \\
88.63 & 1.103 & 4.1 \\
88.94 & 1.1 & 5.5 \\
\hline
\end{tabular}

were collected from different parts of the cave. All were soft and mushy and difficult to grind for X-ray analysis. The X-ray patterns for all five samples showed wellcrystallized calcite, some with a trace of gypsum. These speleothems have been referred to as moonmilk and they certainly have the physical appearance and texture of moonmilk. However, no trace of the usual moonmilk minerals (hydrated magnesium carbonates such as hydromagnesite) were detected. To the extent that moonmilk is a textural term and not a mineralogical term, it is legitimate to call these coatings moonmilk, but those examined, at least, are calcite moonmilk.

A sample of the chalk-white blobs about one $\mathrm{cm}$ in diameter was collected from the wall near the blue-green stalactites. The individual crystals were too small to resolve under the binocular microscope. The speleothem was wet, sticky and had a stringy character. Nevertheless, the X-ray pattern was that of well-crystallized calcite superimposed on a broad maximum typical of non-crystalline material (Fig. 7). There may well be an organic substructure to the stringy speleothems with an overgrowth of calcite, which is the only phase that would produce an X-ray diffraction pattern. X-ray patterns of other stringy deposits also exhibited a very broad hump indicating the presence of amorphous material

In the Kipuka Kanohina Cave System occur bright blue-green stalactites (Fig. 8). These were confirmed to be a copper mineral by Elhard and Coons (2004), who published a color photograph. The speleothems are located about $400 \mathrm{~m}$ down-tube from the Tapa Street Entrance in a section where the passage walls are polished shiny-black lava. It was possible to get permission from the land owner to remove one 2-cm-long stalactite. There were several surprises when the specimen reached the laboratory. Unlike the green coating in Lama Lua, the Kipuka Kanohina specimen had dried in transit and essentially fell off of the underlying stalactite as a loose powder. The blue-green material was a coating over a normal black lava stalactite. The 2-cm stalactite easily yielded a few milligrams of powder. The next surprise was the X-ray diffraction pattern. The sample didn't have one. The bluegreen material was non-crystalline at the X-ray diffraction scale. The X-ray emission spectrum showed that the dominant elements are $\mathrm{Si}$ and $\mathrm{Cu}$ with smaller amounts of $\mathrm{Ca}$ and $\mathrm{Al}$ (Fig. 9). A spatial scan of X-ray emission 


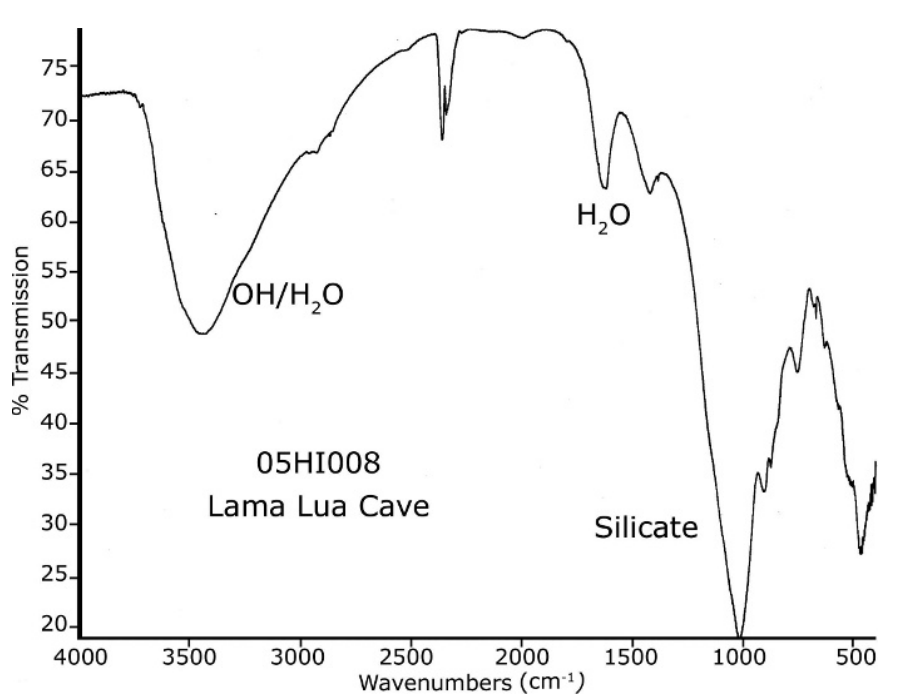

Figure 6. Infrared absorption spectrum for green mineral from Lama Lua Cave. One mg of scraping was ground with $200 \mathrm{mg} \mathrm{KBr}$ and vacuum cold-pressed into a transparent pellet for transmission measurement on a Nicholet Fourier Transform spectrometer.

over the area of an SEM image shows that the elemental distribution is highly uniform, indicating a single noncrystalline phase (Fig. 10). Overall, the blue-green coating is a nearly pure copper silicate. However, because it is noncrystalline, it is technically not a mineral. The infrared spectrum (Fig. 11) shows that the phase is highly hydrated, so it can be best described as a copper silicate gel. The chemical composition is similar to chrysocolla, $(\mathrm{Cu}, \mathrm{Al})_{2} \mathrm{H}_{2}-$ $\mathrm{Si}_{2} \mathrm{O}_{5}(\mathrm{OH})_{4} \cdot \mathrm{nH}_{2} \mathrm{O}$, but lacks crystallinity.

\section{High Altitude Caves on Mauna Loa}

There are many lava tubes, some mineralized, on the north side of Mauna Loa in the general area of Relay Junction (Medville, 1997). One of the most interesting caves was found high on Mauna Loa. It is reached from the side road that leads from the Saddle Road to the NOAA Observatory. About $6 \mathrm{~km}$ along contour from Relay Junction there is the black 1843 pahoehoe flow bounded on both sides by more recent brown aa flows. Less than one
Table 3. Normalization of the chemical analysis of sample $05 \mathrm{HI} 006$ to a chemical formula.

\begin{tabular}{lccc}
\hline Oxide & Mean Wt (\%) & Mole Fraction & Normalized \\
\hline $\mathrm{CuO}$ & 31.97 & 0.402 & 3.98 \\
$\mathrm{~V}_{2} \mathrm{O}_{5}$ & 18.37 & 0.101 & 1.00 \\
$\mathrm{~K}_{2} \mathrm{O}$ & 0.07 & 0.001 & 0.01 \\
$\mathrm{Al}_{2} \mathrm{O}_{3}$ & 1.25 & 0.012 & 0.12 \\
$\mathrm{SiO}_{2}$ & 29.47 & 0.491 & 4.86 \\
$\mathrm{MgO}$ & 7.98 & 0.198 & 1.96 \\
$\mathrm{CaO}$ & 0.74 & 0.013 & 0.13 \\
$\mathrm{Total}$ & 89.85 & & \\
$\mathrm{H}_{2} \mathrm{O}$ & 10.15 & 0.564 & 5.58 \\
\hline
\end{tabular}

Rounded composition: $2 \mathrm{MgO} \cdot 4 \mathrm{CuO} \cdot \mathrm{V}_{2} \mathrm{O}_{5} \cdot 5 \mathrm{SiO}_{2} \cdot 5.6 \mathrm{H}_{2} \mathrm{O}$

kilometer downslope from the road, there is a string of pukas that mark the route of a collapsed tube. One of these first appeared to be a simple collapse structure with a small alcove at the downslope end. However, at the upper end was another collapse into a lower tube. The lower tube continued downslope beneath the upper collapse until it choked off at about $60 \mathrm{~m}$ (Fig. 12). It is here called Sample Cave and it is unknown whether or not the cave has been previously cataloged.

There is a pile of white powder on the floor of the small alcove at the downslope end of the collapsed upper tube and white crusts on the walls. The white powder is thenardite, $\mathrm{Na}_{2} \mathrm{SO}_{4}$; the crusts are gypsum. Thenardite also appears as a wall coating at places in the puka where the surface is protected from direct rainfall. Thenardite is the dehydration product of mirabilite, $\mathrm{Na}_{2} \mathrm{SO}_{4} \cdot 10 \mathrm{H}_{2} \mathrm{O}$, a highly water-soluble mineral that occurs in some extremely dry limestone caves. A sample of the floor crust near the entrance of the lower tube contained a mixture of about $60 \%$ thenardite, $20 \%$ gypsum and $20 \%$ mirabilite. A sample from another cave high on Mauna Loa also contained a mixture of mirabilite and thenardite. These caves, high on the volcano, are sufficiently dry to preserve these watersoluble salts. There is an equilibrium between mirabilite and thenardite that depends on both temperature and water vapor partial pressure (White, 1997). The hydration state of any specific specimen will depend on the exact

Table 2. Electron microprobe analysis of green Lama Lua specimen 05HI006. All elements reported as weight percent of the specified oxide.

\begin{tabular}{lccccccc}
\hline Grain & $\mathrm{CuO}$ & $\mathrm{V}_{2} \mathrm{O}_{3}$ & $\mathrm{~K}_{2} \mathrm{O}$ & $\mathrm{Al}_{2} \mathrm{O}_{3}$ & $\mathrm{SiO}_{2}$ & $\mathrm{MgO}$ & $\mathrm{CaO}$ \\
\hline 1 & 33.551 & 16.368 & 0.037 & 1.277 & 27.866 & 7.378 & 0.853 \\
2 & 35.437 & 17.799 & 0.064 & 1.137 & 26.465 & 7.390 & 0.645 \\
3 & 32.056 & 14.958 & 0.055 & 1.066 & 28.891 & 7.725 & 0.684 \\
4 & 32.045 & 14.202 & 0.106 & 1.449 & 30.453 & 7.818 & 0.690 \\
5 & 28.005 & 13.584 & 0.054 & 1.402 & 31.554 & 8.400 & 0.603 \\
6 & 31.276 & 14.833 & 0.066 & 1.128 & 29.933 & 8.695 & 0.625 \\
7 & 31.416 & 14.526 & 0.099 & 1.270 & 31.127 & 8.469 & 1.058 \\
\hline
\end{tabular}




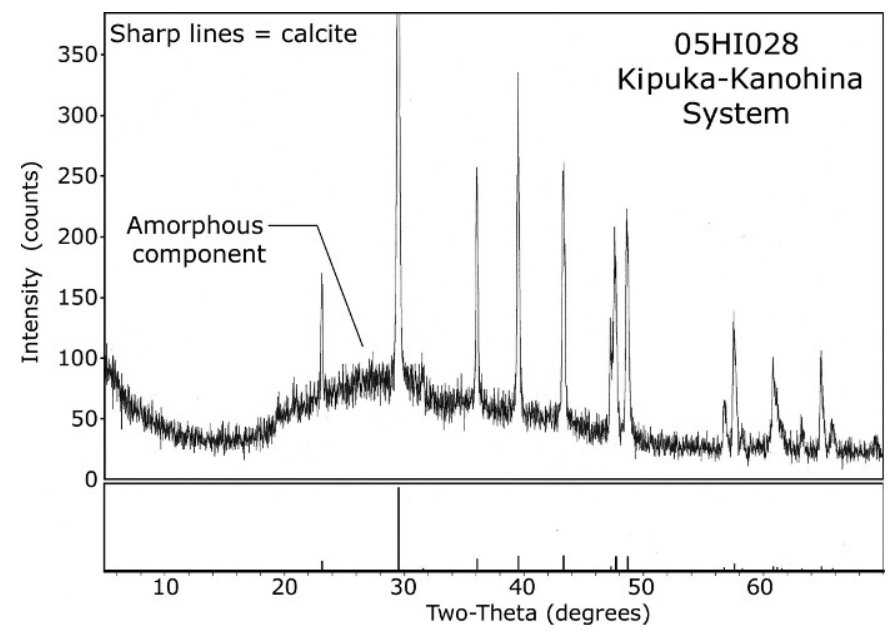

Figure 7. X-ray diffraction pattern for specimen $05 \mathrm{HI} 028$, white stringy material from the Kipuka Kanohina System.

amount of moisture in the local environment and may well change between wet and dry seasons.

The entrance area of the lower tube is encrusted with masses of crystals, some pure white and some tinged with yellow and orange (Fig. 13). A breakdown block at the cave entrance is coated with clear crystals up to a centimeter across (Fig. 14). Of the three samples analyzed by X-ray diffraction, all gave clean patterns of wellcrystallized gypsum. Sample Cave has the most dramatic display of crystals of any of the caves examined, but the mineral is the same gypsum found in many limestone caves.

Dendritic clusters of clear crystals a few millimeters in length were observed in Red Spirit Pit. These proved to be gypsum although with a more acicular habit than those observed in Sample Cave.

\section{Caves of the Kilauea Caldera}

Kilauea Caldera contains dozens of small fumarole and tumulous caves. Some of these were steaming with a strong smell of $\mathrm{SO}_{2}$ and maybe some $\mathrm{HCl}$. Air temperature in some reached the range of $50{ }^{\circ} \mathrm{C}$. There are white coatings on many of the caves and some of the fumaroles are depositing clear yellowish crystals (Fig. 15). White Stalactite Cave is a shallow trench with a short tunnel with walls coated by thick white and yellow crystals. In the absence of a collecting permit, it was not possible to obtain samples and the mineralogical characterization of these deposits remains a project for the future. The size and morphology of the clusters of crystals are similar to the gypsum crystals observed in Sample Cave. The yellow color might be due to small amounts of included elemental sulfur.

\section{Discussion AND Conclusions}

Overall, 51 samples were obtained from nine caves. Of these 51 samples, 22 were calcite and 15 were gypsum. Calcite appeared as coralloids, as crusts, and as the stringy

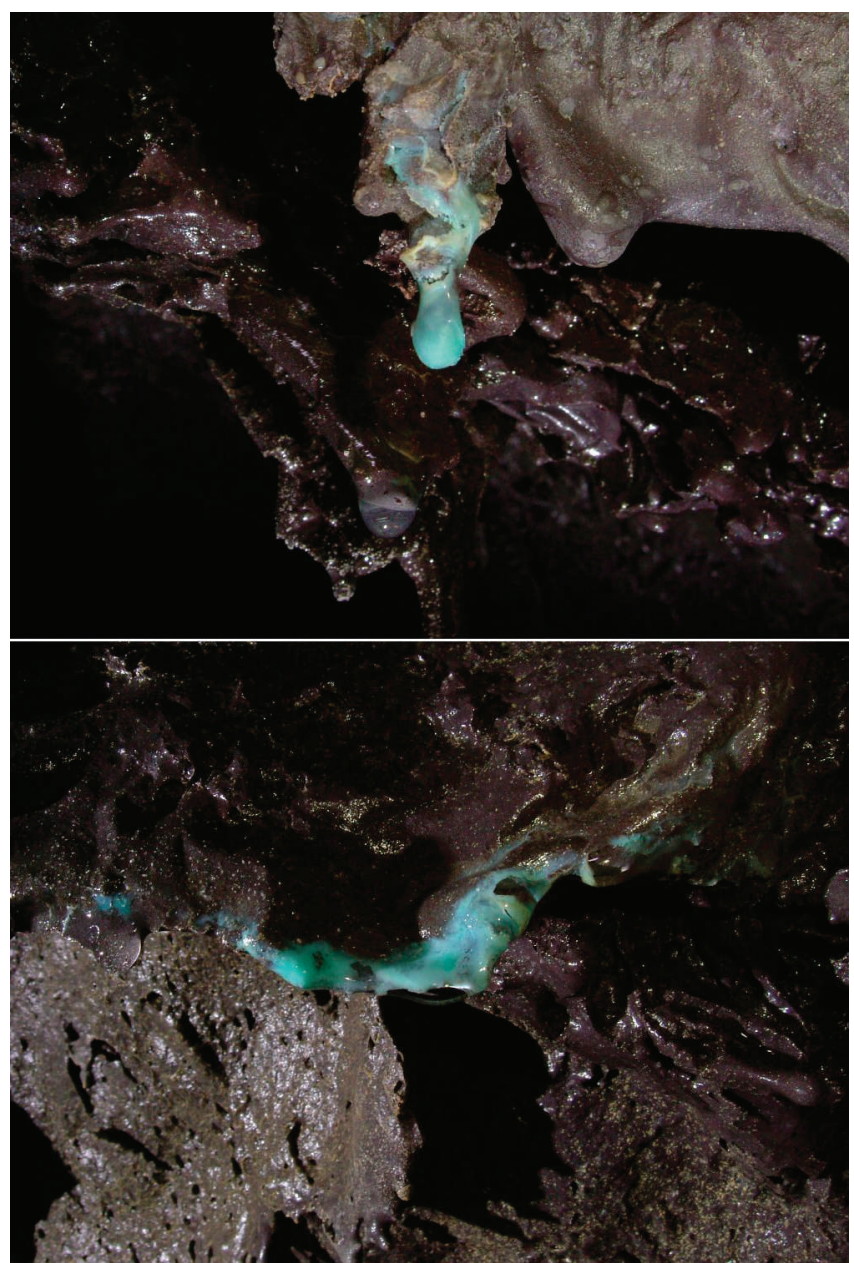

Figure 8. Photographs of the blue-green stalactites in the Kipuka-Kanohina System.

white masses from the Kipuka Kanohina System. Gypsum sand and crusts were found in the Hualalai Ranch System, the Kipuka Kanohina System, Bee Cave, Black Pellet Cave, Kiholo Bay Cave, Sample Cave, and Red Spirit Pit. Except for the copper and vanadium minerals, the secondary speleothems in this group of lava tube caves are not intrinsically different from speleothems found in many limestone caves. However, the most common features of limestone caves, calcite stalactites, stalagmites, and flowstone, were not observed. Although calcite was the most common mineral observed, it always appeared in the form of coralloids, moonmilk, or powdery crusts.

\section{Sulfate Minerals}

The presence of sulfate salts is the result of evaporation of the seepage waters that enter the caves, especially caves that are still hot. When the caves cool and are wetted from rainfall seepages, as is true of most of the low altitude caves, only the ubiquitous gypsum survives. The more highly soluble salts only survive in the higher and drier caves. Thenardite and mirabilite, which convert rapidly into each other depending on temperature and moisture 


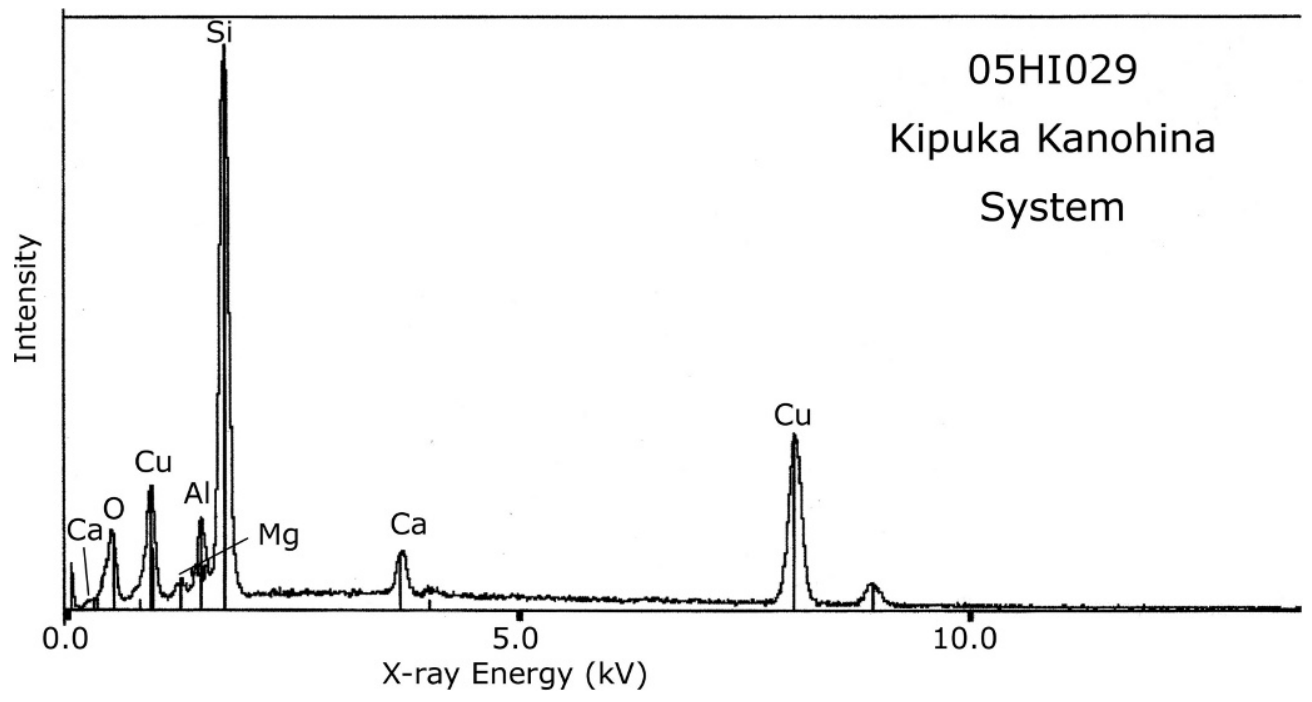

Figure 9. X-ray emission spectrum of the blue green coating from lava stalactites (sample 05HI029).

content, were found in this investigation and have been reported in other caves such as Lae'apuki (Porter, 2000). In addition, Lae'apuki Cave contains large and extensive speleothems of blödite, $\mathrm{Na}_{2} \mathrm{Mg}\left(\mathrm{SO}_{4}\right)_{2} \cdot 4 \mathrm{H}_{2} \mathrm{O}$, and kainite, $\mathrm{KMg}\left(\mathrm{SO}_{4}\right) \mathrm{Cl} \cdot 3 \mathrm{H}_{2} \mathrm{O}$. Unpublished mineral analyses of the
USGS's Hawaiian Volcano Observatory also list hydroglauberite, $\mathrm{Na}_{10} \mathrm{Ca}_{3}\left(\mathrm{SO}_{4}\right)_{8} \cdot 6 \mathrm{H}_{2} \mathrm{O}$.

As noted by Forti (2005), these highly water-soluble minerals are transient phases. As the host lava tubes cool to ambient conditions, these minerals dissolve and are lost.
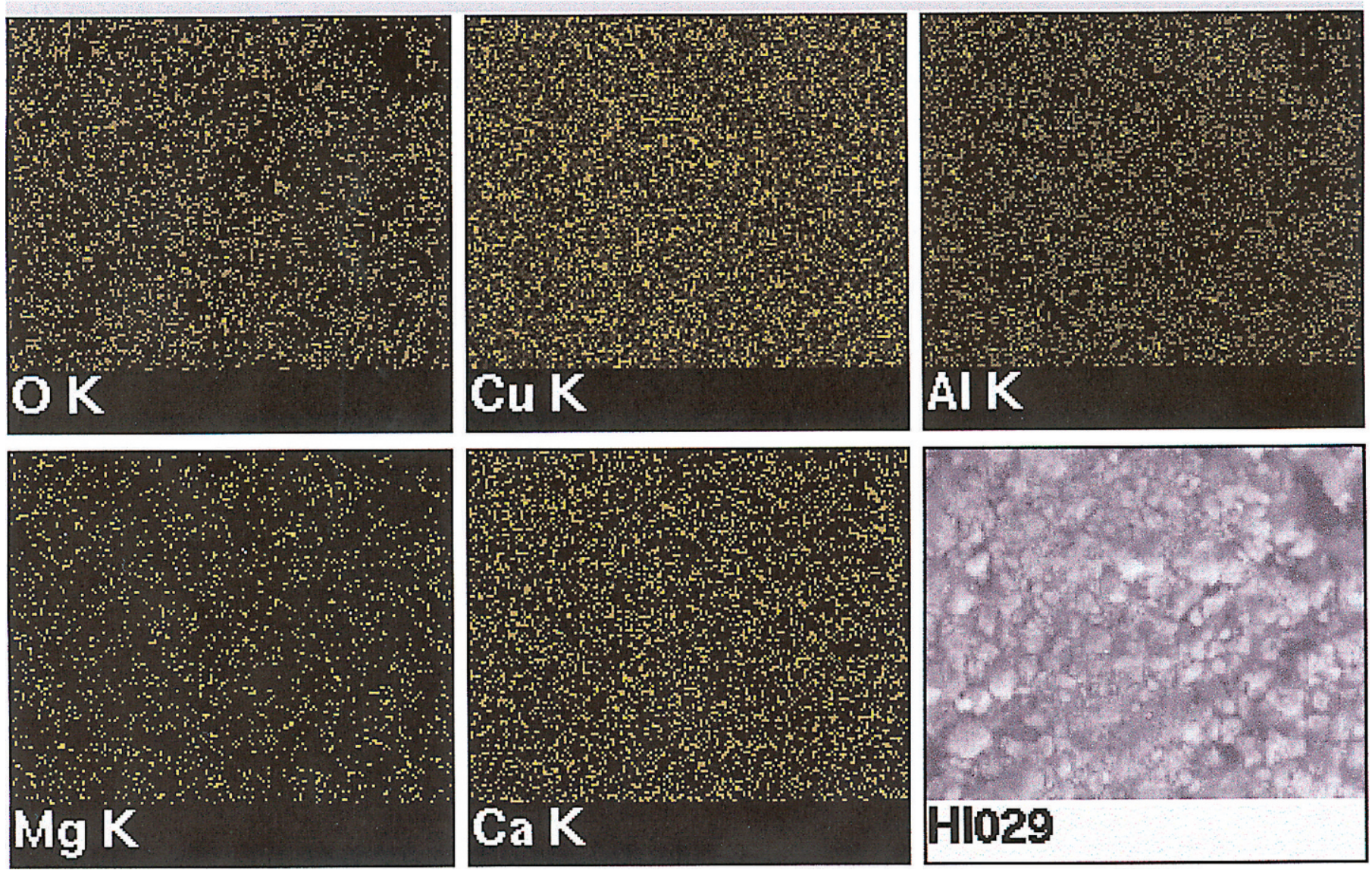

Figure 10. X-ray emission map of the SEM image of sample 05HI029 (shown in lower right). 


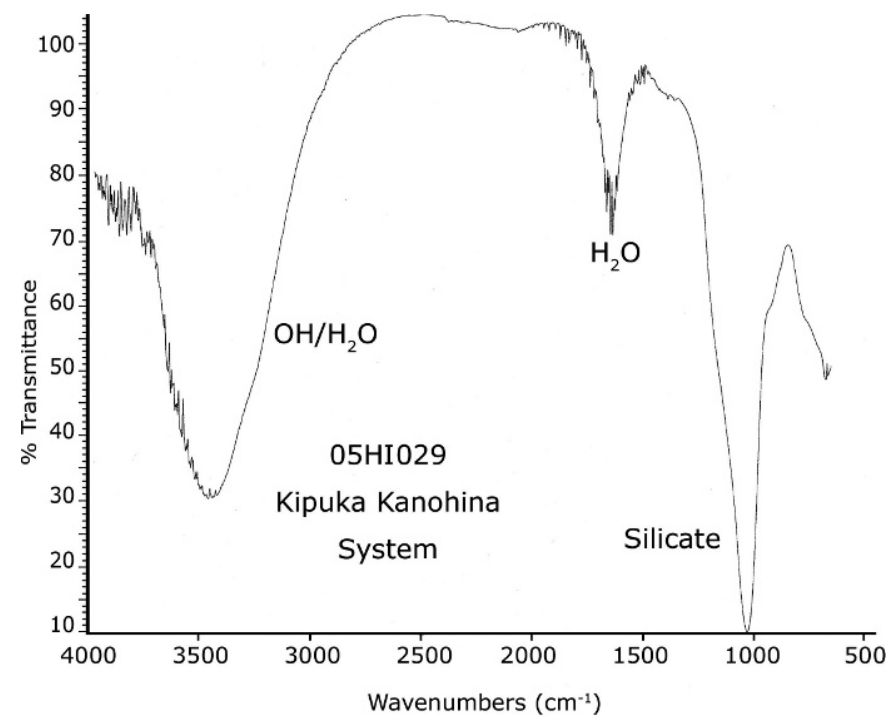

Figure 11. Infrared absorption spectrum for blue-green coating, sample 05HI029.

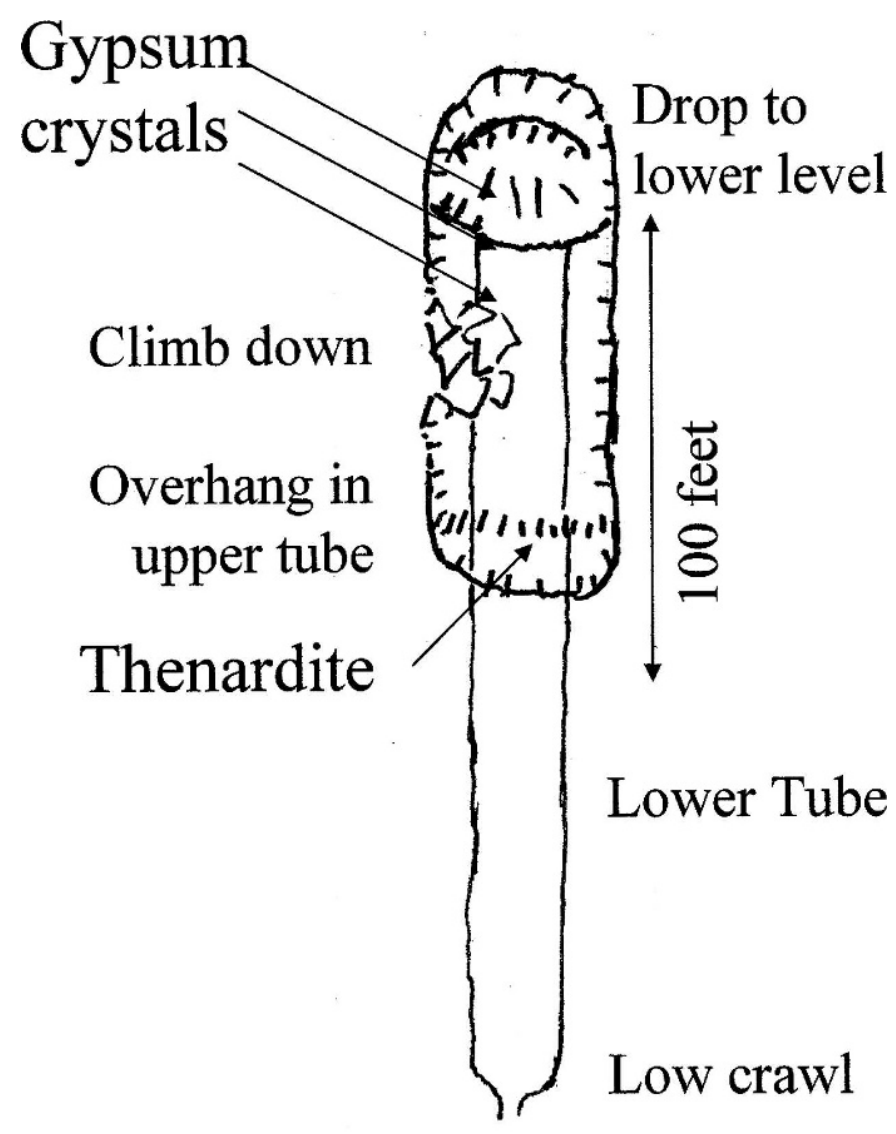

\section{Sample Cave}

Figure 12. Sketch map of Sample Cave.

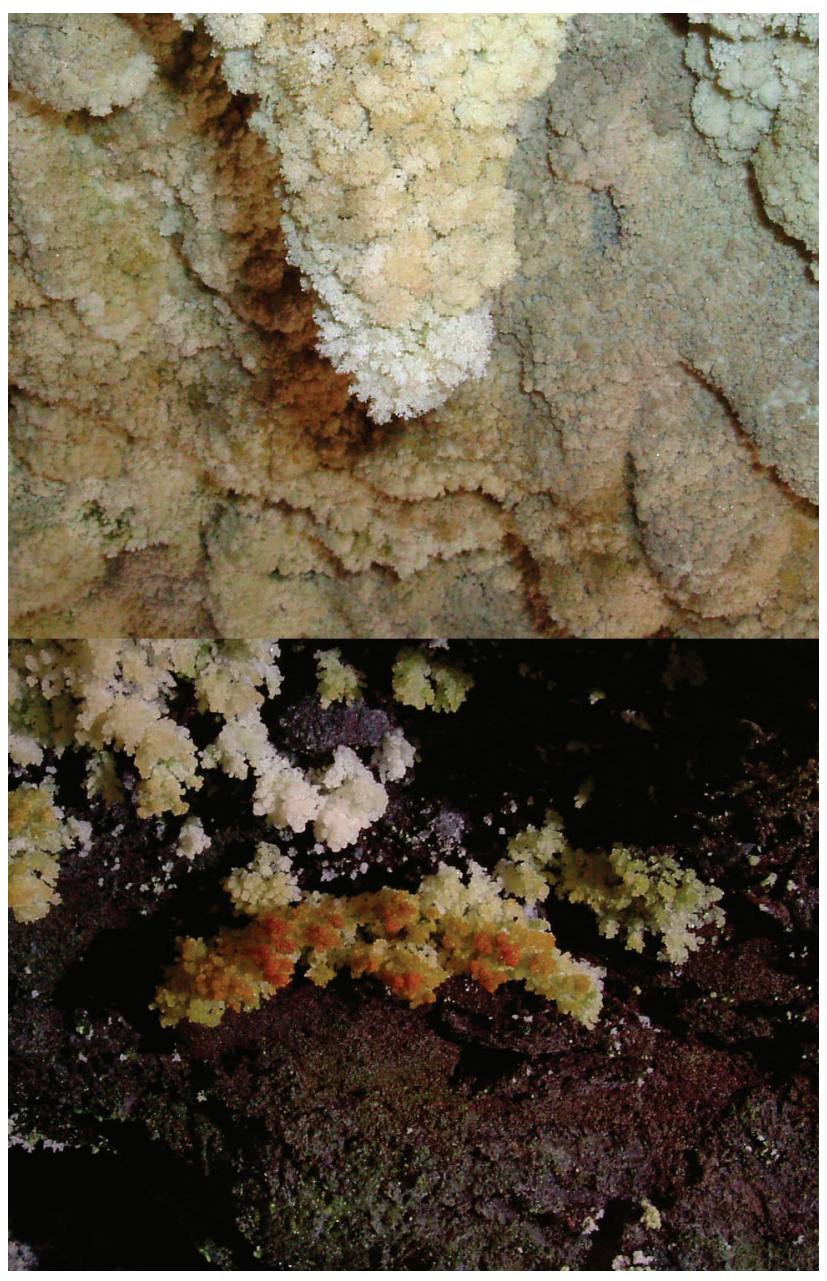

Figure 13. (Upper) Crystal-covered surface near entrance of Sample Cave. (Lower) Orange-tinged crystal mass inside Sample Cave.

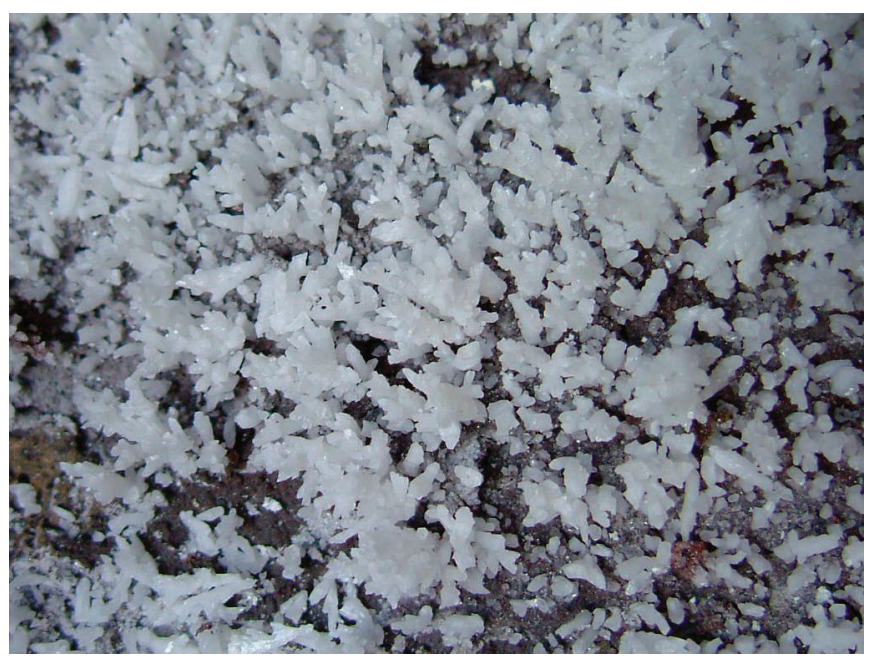

Figure 14. Clear crystals on breakdown block inside drip line of Sample Cave.

Journal of Cave and Karst Studies, August 2010•83 


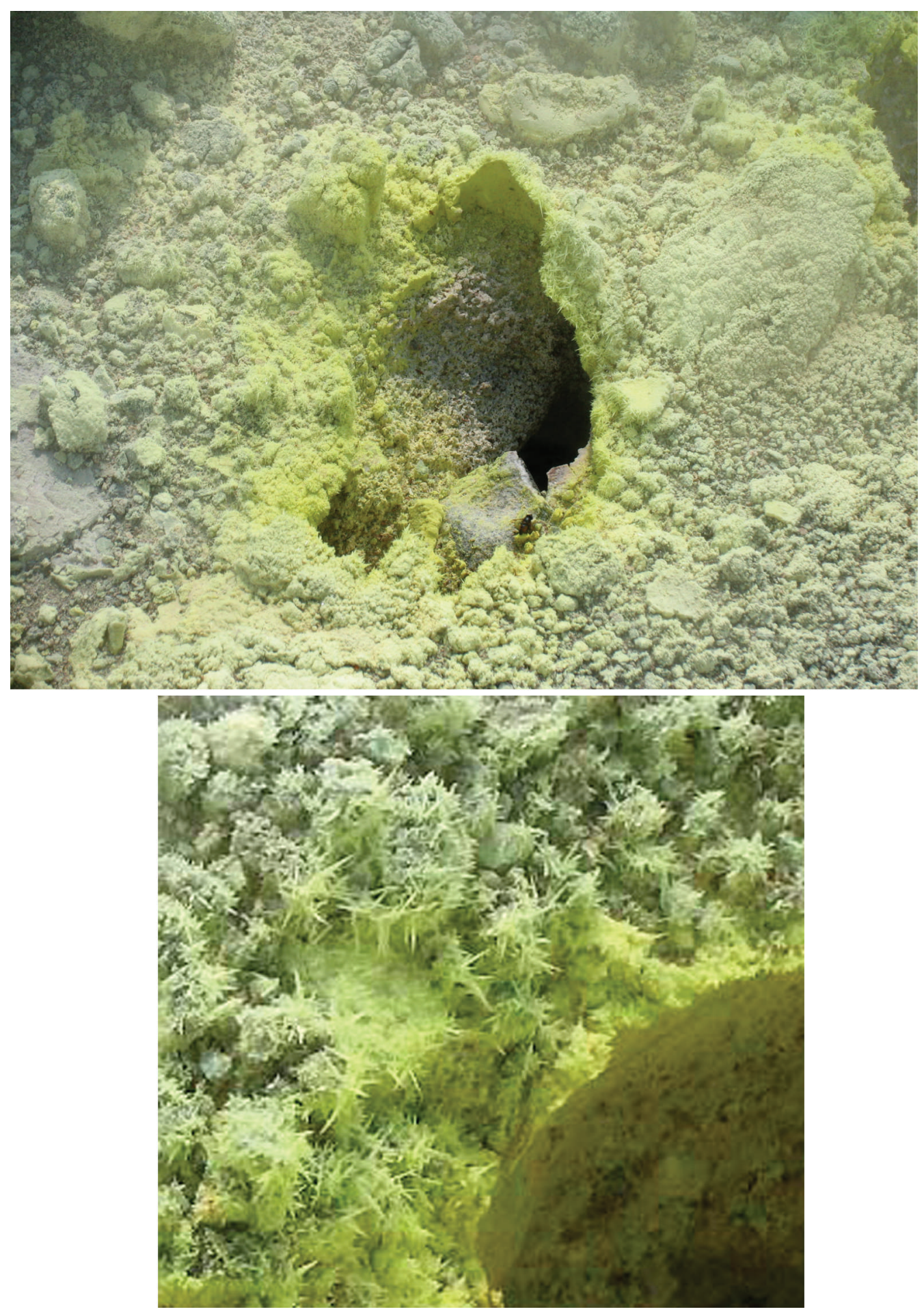

Figure 15. Crystals deposited around small fumarole in Kilauea Caldera.

Lae'apuki Cave was only two-years-old when Porter and his companions did their exploration. Follow-up investigations at regular intervals to observe changes in mineralogy with time and temperature would have been very interesting.

Palmer and Palmer (2006) reported bassanite, $\mathrm{CaSO}_{4}$. $1 / 2 \mathrm{H}_{2} \mathrm{O}$ from Refuge Cave, part of the Kipuka-Kanohina
System. Bassanite is unstable in the presence of water at ambient temperature; it quickly hydrates to form gypsum. Its presence in a cave now cooled to ambient temperature is evidence that some of the gypsum may also have been formed in the presence of high temperature gases and not just as a cold-water deposit formed under present day conditions. 


\section{Calcite Speleothems}

The mechanism by which calcite speleothems are deposited in limestone caves is well-established and known in considerable detail. Infiltrating rainwater encounters the $\mathrm{CO}_{2}$-rich soil atmosphere and dissolves $\mathrm{CO}_{2}$ to concentrations orders of magnitude greater than the atmospheric values. When the acidic $\mathrm{CO}_{2}$-rich water reaches the soil/limestone contact, there is a reaction and the limestone is dissolved. Those portions of the infiltration water that intersect an underlying cave passage are exposed to the lower $\mathrm{CO}_{2}$ pressure of the cave atmosphere and excess $\mathrm{CO}_{2}$ is degassed, thus supersaturating the drip water and forcing the precipitation of $\mathrm{CaCO}_{3}$.

The $\mathrm{CO}_{2}$ portion of the mechanism should work equally well in volcanic caves. The missing bit of the mechanism is the source of calcium. Instead of limestone, which dissolves readily in acidic groundwater, the source of calcium in volcanic caves is likely from the breakdown of anorthite feldspar (the more calcium-rich side of the plagioclase solid solution series, $\left.\mathrm{Na}_{\mathrm{x}} \mathrm{Ca}_{(1-\mathrm{x})} \mathrm{Al}_{(2-\mathrm{x})} \mathrm{Si}(2+\mathrm{x}) \mathrm{O}_{8}\right)$ in the basaltic rock. Anorthite is the least stable of the common basaltic minerals. It breaks down in water roughly 100 times faster than the pyroxene minerals and 5000 times faster than olivine (Lasaga, 1984). The calcium end-member of the plagioclase series breaks down roughly 100 times faster than the sodium-end member and several thousand times faster than orthoclase, $\mathrm{KAlSi}_{3} \mathrm{O}_{8}$. Although the instability of calcium-rich feldspar provides a ready source of calcium for the deposition of calcite and gypsum, the rates of dissolution are much slower than those of limestone. The absence of massive calcite speleothems (stalactites, stalagmites, and flowstone) may be the result of there being only a weak source of calcium for the seepage water, or it might be due to low $\mathrm{CO}_{2}$ pressures in the overlying soils. Investigations of the chemistry of the drip water in volcanic caves will be necessary to sort out the possible geochemical mechanisms.

\section{Transition Metal-Containing Minerals}

The copper silicate from the Kipuka-Kanohina System and the copper-vanadium silicate from Lama Lua Cave appear to be both fumarole minerals, deposited in pre-existing lava tubes by hot steam or other gases. The source of the copper and vanadium is likely the lava itself. Trace element analyses of basalts in general (Prinz, 1967) and Hawaiian basalts in particular (Wager and Mitchell, 1953) show typical copper concentrations in the range of $100 \mathrm{ppm}$ and vanadium concentrations of several hundred $\mathrm{ppm}$. The transport species is likely to have been a chloride complex. Both copper and vanadium chlorides are volatile at the temperatures of fumarole gases and this would account for stripping relatively pure copper and vanadium compounds from a rock in which the elements were present at only part-per-million quantities. The presence of kainite in the still-hot Lae'apuka Cave is evidence that chloride is present in the gases of young lava tubes.

The failure to identify the copper-vanadium mineral in Lama Lua cave, in spite of a reasonably accurate chemical composition and a reasonably good quality X-ray diffrac- tion pattern, raises the possibility that it is a new mineral. However, a much more extensive characterization effort would be required before a new mineral would be accepted by the International Commission on New Mineral Names.

\section{ACKNOWLEDGEMENTS}

Elizabeth L. White is thanked for her assistance in the field and with preparing the illustrations used in this article. Nevin and Judy Davis showed us mineralized areas in the caves near Kona. Judy Davis sampled some of the caves. Nevin Davis (Figs 4, 8, 13, and 14) and John Wilson (Figs 1 and 3) generously permitted use of some of their photographs in this article. Don Coons guided us to interesting features in the Kapuka Kanohina System. We thank William R. Halliday for an extensive walking tour of the caves of Kilauea Caldera. The X-ray diffraction patterns were measured by Nichole Wonderling and the microprobe analysis by Mark Angelone at Penn State's Materials Characterization Laboratory. I thank Ellen Herman for her assistance with the SEM.

\section{REFERENCES}

Baird, A.K., Mohrig, D.C., and Welday, E.E., 1985, Vapor deposition in basaltic stalactites, Kilauea, Hawaii: Lithos, v. 18, p. 151-160.

Coons, D., 2004, Speleogenesis of the Kipuka-Kanohina Cave System: NSS News, v. 62, p. 42-43.

Davis, N.W., 2006, Bee Cave: Hawaii Speleological Survey Newsletter, no. $19,6 \mathrm{p}$

Elhard, R., and Coons, D., 2004, Mineralogy of the Kipuka Kanohina Cave System: NSS News, v. 62, p. 44-45.

Elhard, R., and Herrera, R., 2004, Caves in our front yard: NSS News, v. 62, p. $36-41$.

Forti, P., 2000, Mineralogenic mechanisms and cave minerals in the volcanic caves of Mt. Etna (Sicily, Italy): Mitteilungen des Verbandes der deutschen Höhlen- und Karstforscher e.v. München, v. 46, p. 37-41.

Forti, P., 2005, Genetic processes of cave minerals in volcanic environments: An overview: Journal of Cave and Karst Studies, v. 67, p. 3-13.

Hill, C.A., and Forti, P., 1997, Cave minerals of the world, $2^{\text {nd }}$ Edition, Huntsville, National Speleological Society, 463 p.

Lasaga, A.C., 1984, Chemical kinetics of water-rock interactions: Journal of Geophysical Research, v. 89, p. 4009-4025.

Medville, D., 1997, The lava tubes of north Mauna Loa: NSS News, v. 55, p. 32-43.

Medville, D., 2005, Black Pellet Cave: Hawai'i Speleological Survey Newsletter, no. 17, p. 14-17.

Medville, D., 2006a, Some caves near Kiholo Bay: Hawai'i Speleological Survey Newsletter, no. 20, p. 20-21.

Medville, D., 2006b, The exploration and survey of the Lama Lua System - North Kona, Hawai'i: Hawai'i Speleological Survey Newsletter, no. 20 , p. $3-7$.

Medville, D., and Davis, N.W., 2007, The exploration and survey of the Lama Lua System - North Kona, Hawai'i: NSS News, v. 65, p. 10-17.

Palmer, P., and Palmer, A., 2006, Mineral deposits in the Refuge Cave, Kipuka Kanohina System, Hawai'i: Hawai'i Speleological Survey Newsletter, no. 19 , p. 3-5.

Porter, A., 2000, The initial exploration of Lower Lae'apuki Cave System, Hawai'i Volcanoes National Park: NSS News, v. 58, p. 10-17.

Prinz, M., 1967, Geochemistry of basaltic rocks: Trace elements, in Hess, H.H. and Poldervaart, A., eds., Basalts, New York, Wiley Interscience, v. 1, p. 271-323.

Wager, L.R. and Mitchell, R.L., 1953, Trace elements in a suite of Hawaiian lavas: Geochimica et Cosmochimica Acta, v. 3, p. 217-223.

White, W.B., 1997, Thermodynamic equilibrium, kinetics, activation barriers, and reaction mechanisms for chemical reactions in karst terrains: Environmental Geology, v. 30, p. 46-58. 